\title{
Effect of long term oxygen treatment at home in children with pulmonary vascular disease
}

\author{
JEAN J BOWYER, * CAROLINE M BUSST, DAVID M DENISON, \\ ELLIOT A SHINEBOURNE
}

From the Departments of Paediatric Cardiology and Respiratory Physiology, Brompton Hospital, London

SUMMARY Inhalation of $100 \%$ oxygen by nine children with pulmonary vascular disease increased pulmonary blood flow measured at cardiac catheterisation; there was no significant change in pulmonary artery pressure. Fifteen children with pulmonary vascular disease that was severe enough to preclude corrective cardiac operation were studied to determine the effect of long term oxygen treatment on pulmonary vascular disease. Nine received long term domiciliary oxygen for a minimum of twelve hours a day for up to five years. Though the untreated group closely resembled the treated group their survival was significantly less good. All nine treated children are alive whereas five of the six children who did not receive oxygen have died.

Pulmonary vascular resistance is often raised in children with congenital heart defects and is always raised in those with primary pulmonary hypertension, which is a rare condition. In many such children the pulmonary vascular resistance can be reduced by a pulmonary vasodilator such as oxygen, tolazoline, or epoprostenol (prostacyclin). But when the resistance remains $>8 \mathrm{~mm} \mathrm{Hg} .1^{-1} \cdot \mathrm{min} \cdot \mathrm{m}^{2}$ (640 dyn.s. $\left.\mathrm{cm}^{-5} . \mathrm{m}^{2}\right)$ during optimal ventilation with $100 \%$ oxygen, surgical repair of the cardiac defect is associated with an unacceptably high risk of perioperative death or may lead to accelerated deterioration in the pulmonary vascular bed. ${ }^{12}$ These children have hypertensive pulmonary vascular disease, and pathological changes in the pulmonary arterioles are invariably found at biopsy. ${ }^{34}$ They also have reduced exercise tolerance and a poor prognosis. At present there is no effective and accepted treatment.

Measurements during cardiac catheterisation (both published ${ }^{5}$ and our own which are described below) show that in all cases that were studied inhalation of $100 \%$ oxygen produced some fall in pulmonary vascular resistance compared with that in air. This shows that there is an additional but

Requests for reprints to Dr J J Bowyer, St Peter's Hospital, Guildford Road, Chertsey, Surrey KT16 OPZ.

^Present address: St Peter's Hospital, Chertsey.

Accepted for publication 10 December 1985 reversible element of vasoconstriction contributing to the raised pulmonary vascular resistance and superimposed on the permanent (irreversible) destructive or obliterative changes in the vascular bed. ${ }^{4}$

Experimental use of crotalaria alkaloids in rats shows that they cause intense pulmonary vasoconstriction followed by obliteration with fibrinoid necrosis. ${ }^{6}$ Wagenvoort and Wagenvoort infer from this, and from the charactertistic siting of the obliterative lesions in patients, that fibrinoid necrosis may be the result of intense vasospasm both in children with primary pulmonary hypertension and in those with intracardiac shunts. ${ }^{4}$

The response to oxygen and the relation of vasospasm to tissue damage suggested that prolonged oxygen treatment might benefit children with persistently raised pulmonary vascular resistance. The hypothesis on which the trial was based is that the local pharmacological effect of oxygen in relieving vasospasm might prevent or delay a cycle of increasing damage in which superimposed (reversible) vasoconstriction would accelerate destructive changes. The trial was prompted by the pronounced improvement noted in two girls with pulmonary vascular disease and cyanosis who had been using domiciliary oxygen for two or three years when the trial began. They continue to use it but are not included in the trial.

By analogy with studies at altitude ${ }^{7}$ and the trials of oxygen treatment in patients with chronic 
Table 1 Data on individual patients

\begin{tabular}{|c|c|c|c|c|c|c|c|c|c|}
\hline \multirow[t]{2}{*}{ Diagnosis } & \multirow{2}{*}{$\begin{array}{l}\text { Age at } \\
\text { catheter- } \\
\text { isation (yr) }\end{array}$} & \multicolumn{2}{|c|}{$\overline{P A P}(m m H g)$} & \multicolumn{2}{|c|}{$P V R\left(\operatorname{mm~Hg} \cdot l^{-1} \cdot \min \cdot \mathrm{m}^{2}\right)$} & \multicolumn{3}{|c|}{ On entry into trial } & \multirow{2}{*}{$\begin{array}{l}\text { Symptom } \\
\text { score }\end{array}$} \\
\hline & & Air & Oxygen & Air & Oxygen & $\begin{array}{l}\text { Age } \\
1980\end{array}$ & $\begin{array}{l}H b \\
(g / d l)\end{array}$ & $\begin{array}{l}\mathrm{O}_{2} \\
\text { saturation } \\
(\%)\end{array}$ & \\
\hline $\begin{array}{l}\text { Untreated group: } \\
1 \text { Primary PHT } \\
2 \text { A-P window` } \\
3 \text { VSD } \\
4 \text { VSD } \\
5 \text { UVH } \\
6 \text { UVH } \\
\text { Mean } \\
\text { SEM }\end{array}$ & $\begin{array}{r}5 \\
11 \\
8 \\
9 \\
4 \\
2 \\
6 \cdot 5 \\
-\end{array}$ & $\begin{array}{c}70 \\
63 \\
85 \\
85 \\
47 \\
-70 \\
6.4\end{array}$ & $\begin{array}{l}\overline{61} \\
80 \\
85 \\
42 \\
59 \\
65 \\
6.9\end{array}$ & $\begin{array}{l}\overline{33} \\
23 \\
36 \\
12 \cdot 7 \\
\frac{26}{4 \cdot 6}\end{array}$ & $\begin{array}{c}\overline{28} \\
19 \\
25 \\
8 \\
16 \\
19 \\
3 \cdot 1\end{array}$ & $\begin{array}{r}7.5 \\
13.7 \\
11.0 \\
9.5 \\
4.6 \\
7.0 \\
8.9 \\
1.2\end{array}$ & $\begin{array}{r}13 \cdot 8 \\
14 \cdot 3 \\
15 \cdot 1 \\
15 \cdot 9 \\
15 \cdot 4 \\
19 \cdot 3 \\
15 \cdot 6 \\
0.7\end{array}$ & $\begin{array}{l}81 \\
95 \\
85 \\
68 \\
83 \\
74 \\
81 \\
3.5\end{array}$ & $\begin{array}{c}19 \\
33 \\
28 \\
30 \\
17 \\
18 \\
24 \\
2 \cdot 5\end{array}$ \\
\hline $\begin{array}{l}\text { Treated group: } \\
7 \text { Primary PHT } \\
8 \text { DAt } \\
9 \text { VSD } \\
10 \text { VSD } \\
11 \text { VSD } \\
12 \text { VSD + DA } \\
13 \text { Corr TGA } \\
14 \text { AV canal } \\
15 \text { AV canal } \\
\text { Mean } \\
\text { SEM }\end{array}$ & $\begin{array}{l}13 \\
6 \\
0 \cdot 8 \\
7 \\
0 \cdot 8 \\
8 \\
0 \cdot 5 \\
4 \\
3 \\
4 \cdot 8 \\
-\end{array}$ & $\begin{array}{c}39 \\
74 \\
75 \\
58 \\
- \\
\overline{120} \\
60 \\
82 \\
73 \\
8.8\end{array}$ & $\begin{array}{c}50 \\
75 \\
58 \\
70 \\
70 \\
\frac{70}{76} \\
67 \\
3.3\end{array}$ & $\begin{array}{l}\frac{15}{12} \\
\frac{17}{-} \\
\frac{2}{28} \\
17 \cdot 1 \\
25 \\
19 \\
2 \cdot 3\end{array}$ & $\begin{array}{c}8.4 \\
\overline{-} \\
12.5 \\
39 \\
6.4 \\
\overline{11.4} \\
9.6 \\
14.6 \\
4.5\end{array}$ & $\begin{array}{r}14.9 \\
5.5 \\
5.0 \\
9.0 \\
10.2 \\
9.0 \\
7.6 \\
5.1 \\
7.0 \\
8.1 \\
1.0\end{array}$ & $\begin{array}{r}13.9 \\
14.2 \\
15.3 \\
18.2 \\
20.5 \\
17.7 \\
15.0 \\
14.5 \\
18.3 \\
16.4 \\
0.7\end{array}$ & $\begin{array}{c}97 \\
97 \\
86 \\
89 \\
73 \\
83 \\
93 \\
84 \\
76 \\
86 \\
2 \cdot 7\end{array}$ & $\begin{array}{c}24 \\
32 \\
18 \\
25 \\
21 \\
21 \\
22 \\
17 \\
19 \\
22 \\
1.5\end{array}$ \\
\hline
\end{tabular}

^Aortopulmonary window closed age 9 years. +Ductus aeteriosus closed age 3 years.

Conversion factor: traditional units to SI units $-1 \mathrm{~mm} \mathrm{Hg} \cdot 1^{-1} \cdot \min \simeq 80$ dyn.s. $\mathrm{cm}^{-5}$.

PHT, pulmonary hypertension; A-P window, aortopulmonary window; VSD, ventricular septal defect; UVH, univentricular heart; DA, ductus arteriosuis Corr TGA, physiologically corrected transposition of the great arteries; AV canal, atrioventricular canal; $\overline{P A P}$, mean pulmonary artery pressure; PVE pulmonary vascular resistance; $\mathrm{Hb}$, haemoglobin concentration.

bronchitis ${ }^{89}$ we expected that treatment for a minimum of 12-15 hours a day for at least two years would be needed to show a beneficial effect. For this reason the design of the trial was based on two parallel groups without cross over or placebo.

\section{Patients and methods}

Patients considered for the trial were of school age (four to 18 years) and had primary pulmonary hypertension or pulmonary vascular disease secondary to cardiac defects that was severe enough to preclude surgery or had persisted after operation. Patients with important parenchymal lung disease were not included.

Fifteen children entered the trial during 1980 and 1981. The child's paediatrician or cardiologist allocated their patient to the treatment group after full discussion with the parents. The demands of the treatment and the small numbers studied precluded random allocation or the individual matching of controls.

Table 1 shows the underlying diagnosis, mean pulmonary artery pressure, and pulmonary vascular resistance measured during cardiac catheterisation. The treatment and non-treatment groups both contained one child with primary pulmonary hypertension and one child with pulmonary hypertension persisting after operation. Mean age at entry to the trial was similar in the two groups.

The mean pulmonary artery pressures, which where possible were measured both in air and oxygen, are similar in the two groups. Pulmonary vascular resistance was not measured in all patients. Mean pulmonary vascular resistance both in air and oxygen (Table 1) was higher in the untreated group, but these differences did not achieve statistical significance (unpaired $t$ test, $\mathrm{p}>0 \cdot 1$ for both).

At every visit the parents answered two questionnaires designed to assess the child's disability. The first (Table 2) assessed exercise tolerance and the second (Table 3) the extent of troublesome symptoms. A high score suggests subjective well-being.

Table 1 indicates the condition of the children at entry into the trial at the beginning of 1980 when haemoglobin, oxygen saturation, and symptom scores were measured. There were no statistically signficant differences between the two groups.

\section{SELECTION OF PATIENTS FOR \\ TREATMENT}

At the beginning of the trial all the parents knew that surgical correction of their child's disease was impossible and that he or she had a limited life expectancy. The rationale for oxygen treatment was explained and we made it clear that its benefits were unproven.

The parents of the children in the treated group 
Table 2 A questionnaire for parents. A scoring system for the assessment of exercise ability

Please mark the box (or boxes) on each line which best describes your child in the past six months.

Name:

Date:

\begin{tabular}{l|l|l|l|l|l}
\hline & 0 & 1 & 2 & 3 & 4 \\
\hline School & None & $\begin{array}{c}\text { Half time } \\
\text { or less }\end{array}$ & $\begin{array}{c}\text { Less than } \\
\text { full time or } \\
\text { special school }\end{array}$ & $\begin{array}{c}\text { Full time } \\
\text { limited sport } \\
\text { or none }\end{array}$ & $\begin{array}{c}\text { Full time } \\
\text { full sport }\end{array}$ \\
\hline $\begin{array}{l}\text { Walking on } \\
\text { the flat }\end{array}$ & $\begin{array}{c}\text { Breathless } \\
\text { at rest }\end{array}$ & $\begin{array}{c}\text { Breathless } \\
\text { on minimal } \\
\text { exertion }\end{array}$ & $\begin{array}{c}30-50 \text { yards } \\
\text { slowly all } \\
\text { right }\end{array}$ & $\begin{array}{c}100-400 \text { yards } \\
\text { slowly all } \\
\text { right }\end{array}$ & $\begin{array}{c}2 \text { miles } \\
\text { slowly all } \\
\text { right }\end{array}$ \\
\hline Stairs & Never tries & $\begin{array}{c}\text { Difficulty } \\
\text { with 1 } \\
\text { flight }\end{array}$ & $\begin{array}{c}\text { Difficulty } \\
\text { with 2 } \\
\text { flights-1 } \\
\text { all right }\end{array}$ & $\begin{array}{c}\text { 2 flights all } \\
\text { right at } \\
\text { average } \\
\text { speed }\end{array}$ & Normal \\
\hline Running & Never & $\begin{array}{c}\text { Few paces } \\
\text { only }\end{array}$ & $\begin{array}{c}20 \text { yards } \\
\text { gently all } \\
\text { right }\end{array}$ & $\begin{array}{c}100 \text { yards } \\
\text { jogging } \\
\text { all right }\end{array}$ & $\begin{array}{c}\text { Normal } \\
\text { speed } \\
100 \text { yards }\end{array}$ \\
\hline Tiredness & Always & $\begin{array}{c}\text { Very quickly } \\
\text { tired each } \\
\text { day after } \\
\text { school }\end{array}$ & $\begin{array}{c}\text { Frequently } \\
\text { tired }\end{array}$ & $\begin{array}{c}\text { Sometimes } \\
\text { after a } \\
\text { long day }\end{array}$ & Normal \\
\hline
\end{tabular}

were prepared to try oxygen treatment and the paediatricians agreed. Three families of children in the untreated group felt that their girls were so well and free of symptoms that they did not want to remind them of their disease. One of these families planned to start oxygen treatment later if the child deteriorated. The parents of one girl who presented with three episodes of syncope saw no other evidence of disability, though the catheter data suggested very severe disease.

The other three children in the non-treatment group were more clearly disabled-one had a pacemaker and his parents felt that oxygen treatment would complicate his life. The other two were being treated by physicians who were less convinced of the benefit of treatment, though one of these two patients was given oxygen treatment in hospital before he died.

Thus though allocation of the children to the two groups was not random the reasons for choosing or not choosing treatment showed no detectable trend.

\section{METHODS}

\section{Administration of oxygen}

Oxygen was supplied by oxygen concentrators installed in the child's home with outlets to the bedroom and usually also to the sitting room where the child was able to wear the mask for a few hours before going to bed ${ }^{1011}$ Nasal cannulas were tried initially in all cases, but if these proved unacceptable they were replaced by face masks or tents. We emphasised that the trial required oxygen adminis- tration for a minimum of twelve hours a day, preferably fifteen.

Strict monitoring of the use of the machines proved impracticable because of the great geographical spread of patients. But on each visit both the parents and the child were questioned carefully about the number of hours for which oxygen was used, the frequency of equipment breakdowns, and nights missed because of holidays.

\section{Assessment during cardiac catheterisation}

Before inclusion in the trial nine of the fifteen children were studied while breathing air and oxygen during cardiac catheterisation by means of respiratory mass spectrometry. 512 The patients were anaesthetised, intubated with a leak-free endotracheal tube, and ventilated optimally with air to maintain a normal and constant arterial $\mathbf{P C O}_{2}$. Semi-continuous measurements of metabolic gas exchange were made at the same time as pulmonary artery and left atrial pressures were measured, and samples were drawn from the pulmonary artery and pulmonary veins or systemic circulation as appropriate. The total oxygen content of the blood samples was derived from the blood gases and haemoglobin concentration by the tables of Kelman. ${ }^{13}$

The patients were then ventilated with $100 \%$ oxygen for at least 10 minutes, and the end tidal and arterial carbon dioxide concentrations were compared to ensure as steady a state as possible. Measurements were repeated, and the cardiac output and pulmonary vascular resistance were calculated by the method described by Davies et al. ${ }^{5}$ 
Table 3 A questionnaire for parents

It would be most helpful if you would answer the following questions about your child's health in the last 6 months. Please tick the box in the appropriate column for each question.

Patient's name:

Date:

\begin{tabular}{|c|c|c|c|}
\hline & $\begin{array}{l}\text { A major problem } \\
\text { often occurring } \\
0\end{array}$ & $\begin{array}{l}\text { Minor or occasionally } \\
\text { troublesome } \\
1\end{array}$ & $\begin{array}{l}\text { Not a problem } \\
2\end{array}$ \\
\hline \multicolumn{4}{|c|}{ Does he/she have "bad days" of diminished activity? } \\
\hline \multicolumn{4}{|l|}{ Is he/she worse in cold weather? } \\
\hline \multicolumn{4}{|l|}{$\begin{array}{l}\text { Does he/she have: } \\
\text { Headaches? }\end{array}$} \\
\hline \multicolumn{4}{|l|}{ Nose bleeds? } \\
\hline \multicolumn{4}{|l|}{ Chest pain? } \\
\hline \multicolumn{4}{|l|}{ Leg cramps? } \\
\hline \multicolumn{4}{|l|}{ Coughing blood? } \\
\hline \multicolumn{4}{|l|}{ Poor appetite? } \\
\hline \multicolumn{4}{|l|}{ Faints or dizziness? } \\
\hline \multicolumn{4}{|l|}{ Chest infections? } \\
\hline Has he/she changed in the last 6 months? & & & \\
\hline
\end{tabular}

Comments:

Non-invasive assessment of progress

Initial diagnosis and a decision about operation depended on the measurements made during catheterisation. But, in view of the risk of cardiac catheterisation in children with advanced pulmonary vascular disease, we thought it proper to restrict serial assessment during treatment to non-invasive methods. These included a subjective score from a questionnaire, clinical assessment, electrocardiography, echocardiography, and an exercise test. The children were reviewed every six to 12 months for up to five years.

\section{Results}

Figure 1 shows the mean pulmonary artery pressures and pulmonary blood flow in the nine children studied in air and oxygen. There was no significant change in pressure on oxygen, but pulmonary blood flow was consistently increased. This is reflected in the reduction of pulmonary vascular resistance when oxygen was breathed, though this did not fall below $8 \mathrm{~mm} \mathrm{Hg} \cdot 1^{-1} \cdot \min . \mathrm{m}^{2}\left(\bumpeq 640\right.$ dyn.s. $\left.\mathrm{cm}^{-5} \cdot \mathrm{m}^{2}\right)$ in any case.

\section{Acceptability of treatment}

Three children have used nasal cannulas throughout their treatment, four prefer a mask, and the others can only use a tent. Because the equipment can be used in both the bedroom and sitting room, the child's freedom is less restricted. In some cases the provision of oxygen concentrators was delayed for up to 10 months.

\section{Compliance}

Four of the nine children complied well with oxygen treatment. These families chose never to go away, or only go away with an alternative oxygen source. Breakdowns accounted for a maximum of only a week missed per year. These four patients used oxygen for at least 12 hours per day (commonly 14 

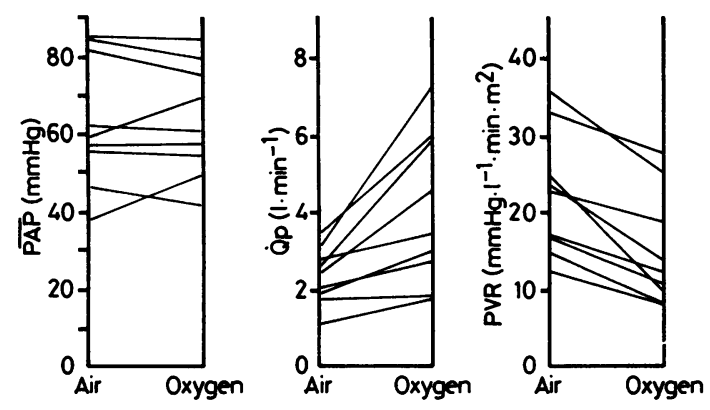

Fig. 1 Data obtained from measurements made during cardiac catheterisation in nine children with advanced pulmonary vascular disease. The mean pulmonary artery pressure $(\overline{P A P})$, pulmonary blood flow $\left(\hat{Q}_{p}\right)$, and pulmonary vascular resistance (PVR) are shown first in air, then after optimal ventilation with $100 \%$ oxygen for ten minutes. $1 \mathrm{~mm} \mathrm{Hg} . \mathrm{l}^{-1} \mathrm{~min} . \simeq 80$ dyn.s.cm ${ }^{-5}$.

hours). Three of the families reported missing up to three weeks a year due to holidays or breakdowns or both. Otherwise these children appear to have had a steady nightly intake of between 10 and 12 hours. All these seven children seem to tolerate treatment well. But two children have found compliance difficult. After two years of successful treatment one adolescent girl found that treatment was intolerable for a four month period during the summer. For a year a boy, who is now fourteen years old and had tolerated treatment for four years, did not comply with treatment. His parents, feeling that his own perception of the quality of his life was paramount, have agreed to his stopping oxygen treatment.

\section{Survival}

Figure 2 shows the survival of the children in the two groups. All nine children on oxygen treatment are alive whereas five of the six children not on treatment have died $\left(\chi^{2}=9.0, p<0.01\right.$ with Yates's cor-

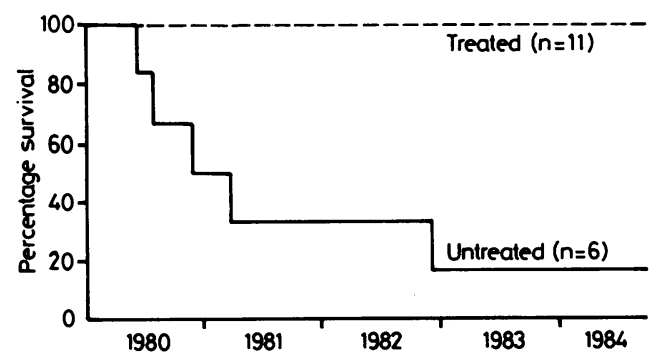

Fig. 2 A chart showing the survival in the years 1980-84 of children with pulmonary vascular disease in the treated and untreated groups. rection). In one child death was thought to be due to a sudden arrhythmia, and another child died after a severe chest infection. Three others became unwell over a period of one to three weeks with increasing cyanosis and exercise intolerance. Only one showed signs of congestive right ventricular failure.

\section{Discussion}

We have shown that there is an additional reversible vasoconstrictive component in most children with severe pulmonary vascular disease. This vasoconstriction can be minimised by optimal ventilation and added oxygen, and is exacerbated by hypoventilation or acidosis. To avoid unwarranted classification of such cases as inoperable, cardiac output must be initially measured under optimal conditions. Figure 1 shows that reliance on changes in pressure alone will lead to important haemodynamic changes being missed. More studies of this type are needed both to define more accurately the risks of operation at different levels of vascular resistance and to determine the correlation between resistance levels and pathological changes in the lungs.

If despite optimal ventilation the pulmonary vascular resistance remains high, operation is contraindicated, and the likely course is one of progressive deterioration. Figure 2 shows that this deterioration can be modified, and survival can be improved.

Deterioration in children with the Eisenmenger complex is associated with increasing right to left shunting which results in a critically low pulmonary blood flow rather than in congestive failure of the right ventricle. There is therefore no reason to suppose that effective pulmonary vasodilatation in this situation causes increased right ventricular work.

This small pilot study shows that long term oxygen treatment at home is well tolerated and improved survival of children with pulmonary vascular disease over a five year period. We believe that the results warrant a larger trial, perhaps at several centres. Recruitment into the trial must be preceded by accurate measurements of pulmonary blood flow under optimal and controlled conditions.

\section{References}

1 Vogel JHK, Brover RF, Jamieson G, Blount SG. Long-term physiological observations in patients with ventricular septal defects and increased pulmonary vascular resistance. Adv Cardiol 1974; 11: 108-13.

2 Friedman W, Heiferman M. Clinical problems of postoperative pulmonary vascular disease. Am $\mathcal{f}$ Cardiol 1982; 50: 631-6. 
3 Heath D, Edwards JE. The pathology of hypertensive pulmonary vascular disease. Circulation 1958; 18: 533-47.

4 Wagenvoort CA, Wagenvoort N. Pulmonary vascular bed-normal anatomy and response to disease. In: Moser KM, ed. Pulmonary vascular disease. New York: Dekker, 1979.

5 Davies NJH, Shinebourne EA, Scallan MJ, Sopwith TA, Denison DM. A study of pulmonary vascular resistance in children with congenital heart disease. Thorax 1984; 39: 895-900.

6 Dingemans KP, Wagenvoort CA. Pulmonary arteries and veins in experimental hypoxia. An ultrastructural study. Am F Pathol 1978; 93: 353-61.

7 Penaloza D, Sime F, Banchero N, Gamboa R, Cruz J, Marticorena E. Pulmonary hypertension in healthy men born and living at high altitudes. $\mathrm{Am} \mathcal{F}$ Cardiol 1963; 1: 150-7.

8 Stuart-Harris C, Flenley DC, Bishop JM, Howard P,
Oldham PD. Long term domicilliary oxygen therapy in chronic hypoxic cor pulmonale complicating chronic bronchitis and emphysema. Lancet 1981; i: 681-6.

9 Nocturnal oxygen therapy trial group. Continuous or nocturnal oxygen therapy in hypoxaemic chronic obstructive lung disease. Ann Intern Med 1980; 93: 391-8.

10 Stark RD, Bishop JM. New method for oxygen therapy in the home using oxygen concentrator. Br Med $\mathcal{F} 1973$; ii: $105-6$.

11 Lowson K, Drummon MF, Bishop JM. Costing new services: long term domiciliary oxygen therapy. Lancet 1981; i: 1146-9.

12 Davies NJH, Denison DM. The measurement of metabolic gas exchange and minute volume by mass spectrometry alone. Respir Physiol 1979; 36: 261-7.

13 Kelman GR. Digital computer subroutine for the conversion of oxygen tension into saturation. $\mathcal{F} A p p l$ Physiol 1966; 21: 1375-6. 